\title{
Penggunaan Smartphone Application Guna Mempelajari Cara Mengurus Jenazah Umat Muslim
}

\author{
Muhamad Awiet Wiedanto Prasetyo ${ }^{1, \mathrm{a},}$ Zulia Karini $^{2, \mathrm{~b},}$ dan Harun Al Ayubi ${ }^{\text {, c }}$ \\ ${ }^{1}$ Program Studi Sistem Informasi, Fakultas Ilmu Komputer, Universitas Amikom Purwokerto \\ ${ }^{2,3}$ Program Studi Teknik Informatika, Fakultas Ilmu Komputer, Universitas Amikom Purwokerto \\ 1,2,3 Jl. Let. Jend. Pol. Soemarto, Kelurahan Purwanegara, Purwokerto Utara, 53123 \\ amawp@amikompurwokerto.ac.id, \\ bulia@amikompurwokerto.ac.id, \\ callayyub81@gmail.com
}

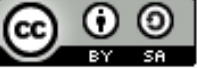

Abstract-The obligation of Muslim towards their relatives who died there are four cases, namely bathing, believing, praying and burying. The community considers that there is no need to think about how to care for the body from the beginning to the finish because there are already their own officers. Rhile in a hadist from 'Aisyah said Rasullah SAW: "Anyone who bathes a corpse and is guarded by trust and cannot be opened (secret) about the protection of the sympathy for the people there hen comes from sin for hs condition. Based on the hadist mentioned the person who mentioned bathe the corpse in priority is his own closest family, then if the family cannot, then other people can do it, while bathing is included in the case of receiving a corpse based on the results of an interview with teacher Madrasah Diniyah Baitul Athfal by agreeing to him about the management of the body, it is expected if it involves family members. Who can use the world od the sunna of the prophet and also in the future can be used as a successor. In Madrasah Diniyah Baitul Athfal involved in the learning process due to shortages in madrasah are short plus students do not have books about the management of bodies or jurisprudence books become obstacles in the process of learning. Teaching lessons for students or instructors. After obtaining data from data collection, .researchers create a system with predetermined and more relevant methods using the Multimedia Development Life Cycle (MDLC) Method. Based on the results obtained for 9352 and included in the category of Good, then the application was validated that can be applied to the research object.

Keywords-Handle Remains, Smartphone Application, Madrasah

Abstrak-Kewajiban muslimin terhadap saudara-saudaranya yang meninggal dunia ada empat perkara yaitu memandikan, mengkafani, menshalatkan dan menguburkanya. Masyarakat menganggap tidak perlu mengetahui cara merawat jenazah dari awal hingga selesai karena sudah ada petugasnya sendiri. Padahal pada suatu hadist dari 'Aisyah bersabda Rasulullah SAW: "Barang siapa memandikan mayat dan dijaga kepercayaan, dan tidak membuka (rahasia) suatu cacat pada simayat kepada orang lain maka keluarlah ia dari segala dosa sebagaimana keadaanya sewaktu baru di lahirkan dari ibunya. Berdasarkan hadist tersebut di sebutkan bahwa orang yang memandikan mayat di utamakan adalah keluarga terdekatnya sendiri barulah jika keluarga tidak bisa, maka boleh orang lain yang mengerjakan, sedangkan memandikan termasuk dalam perkara mengurus jenazah. Berdasarkan hasil wawancara dengan pengajar Madrasah Diniyah Baitul Athfal, dengan diajarkanya tentang pengurusan jenazah di harapkan jika terdapat anggota keluarga yang meninggal dunia nantinya mereka bisa menjalankan sunah nabi dan juga ke depanya dapat menjadi penerus. Pada Madrasah Diniyah Baitul Athfal terdapat permasalahan pada proses pembelajaran karena keterbatasan waktu pelajaran di madrasah yang singkat ditambah para murid tidak memiliki buku tentang pengurusan jenazah atau buku fikih menjadi penghambat dalam proses belajar mengajar bagi murid maupun pengajar. Setelah mendapatkan permasalahan dari pengumpulan data, peneliti melakukan pengembangan sistem dengan metode yang sudah ditentukan dan lebih relevan yaitu menggunakan motode Multimedia Developent Life Cycle (MDLC). Berdasakan hasil yang didapatkan sebesar 9352 dan masuk kategori Baik, maka disimpulkan aplikasi dapat diterapkan pada objek penelitian.

Kata Kunci-Mengurus Jenazah, Smartphone Application, Madrasah

\section{Pendahuluan}

Kewajiban muslimin terhadap saudara-saudaranya yang meninggal dunia ada empat perkara yaitu memandikan, mengkafani, menshalatkan dan menguburkanya [1]. Hukum merawat jenazah sendiri adalah wajib kifayah artinya cukup di kerjakan oleh sebagian masyarakat, bila seluruh masyarakat tidak ada yang merawat maka seluruh masyarakat akan di tuntut di hadapan Allah SWT. Sedangkan bagi orang yang mengerjakanya, mendapat pahala yang banyak di sisi Allah SWT. Pandangan masyarakat, orang yang bertugas menangani perawatan jenazah adalah petugas keagamaan setempat atau biasa disebut Modin [2].

Masyarakat menganggap tidak perlu mengetahui cara merawat jenazah dari awal hingga selesai karena sudah ada petugasnya sendiri. Padahal pada suatu hadist dari 
'Aisyah bersabda Rasulullah SAW : "Barang siapa memandikan mayat dan dijaga kepercayaan, dan tidak membuka (rahasia) suatu cacat pada simayat kepada orang lain maka keluarlah ia dari segala dosa sebagaimana keadaanya sewaktu baru di lahirkan dari ibunya. Sabda nabi lagi: "Hendaklah yang mengaturnya keluarganya sendiri yang terdekat jika dapat memandikan mayat. Tetapi jika tidak dapat, maka siapa saja yang dianggap berhak, karena wara'nya dan amanahnya" (HR. Ahmad).

Berdasarkan hadist tersebut di sebutkan bahwa orang yang memandikan mayat di utamakan adalah keluarga terdekatnya sendiri barulah jika keluarga tidak bisa, maka boleh orang lain yang mengerjakan, sedangkan memandikan termasuk dalam perkara mengurus jenazah. Madrasah Diniyah Baitul Athfal adalah salah satu madrasah yang mengajarkan tentang pengurusan jenazah kepada para peserta didik. Bertujuan untuk melengkapi pendidikan agama Islam yang diperoleh di SD/MI, SMP/MTs, SMA/MA, SMK/MAK atau di pendidikan tinggi dalam rangka peningkatan keimanan dan ketakwaan peserta didik kepada Allah SWT yang penyelenggaraannya bisa dilaksanakan di masjid, mushalla atau di tempat yang memenuhi syarat secara berjenjang atau tidak [3].

Berdasarkan hasil wawancara dengan pengajar Madrasah Diniyah Baitul Athfal, dengan diajarkanya tentang pengurusan jenazah di harapkan jika terdapat anggota keluarga yang meninggal dunia nantinya mereka bisa menjalankan sunah nabi dan juga ke depanya dapat menjadi penerus. Pada Madrasah Diniyah Baitul Athfal terdapat permasalahan pada proses pembelajaran karena keterbatasan waktu pelajaran di madrasah yang singkat ditambah para murid tidak memiliki buku tentang pengurusan jenazah atau buku fikih menjadi penghambat dalam proses belajar mengajar bagi murid maupun pengajar.

Oleh karena itu dibutuhkan media yang dapat digunakan untuk membantu murid dalam melaksanakan proses belajar pengurusan jenazah dan murid juga dapat belajar dimana saja. Pada beberapa penelitian menunjukan penggunaan multimedia pada pembelajaran berpengaruh terhadap hasil belajar serta ada pengaruh yang signifikan pada penggunaan multimedia pembelajaran interaktif terhadap hasil belajar [4].

Begitu juga ada penelitian yang menyatakan bahwa penerapan media pembelajaran berbasis multimedia memiliki pengaruh yang positif terhadap peningkatan motivasi dan hasil belajar [5]. Melihat sekarang ini semakin banyak penggunaan smartphone tentu menjadi peluang untuk memecahkan masalah dalam dunia pendidikan. Semakin banyaknya perangkat bergerak yang ada seperti smartphone, PC tablet, dan handphone proses belajar dapat bersifat personal dan dapat dilakukan dimana saja dan kapan saja [6].

Pada Madrasah Diniyah Baitul Athfal terdapat jumlah 84 murid yang menerima pelajaran tentang pengurusan jenazah. Untuk itu penulis mengadakan survei penggunaan smartphone pada objek penelitian untuk mengetahui apakah penggunaan smartphone dominan digunakan atau tidak. Hasil survei pengguna perangkat smartphone 76 dari sample 84 peserta didik hasil bahwa $90 \%$ murid memiliki smartphone sendiri dan $10 \%$ murid mengaku menggunakan smartphone milik orang tua atau saudara. Responden terdiri dari laki-laki sebanyak 62 persen dan perempuan sebanyak 38 persen dengan usia tiga belas tahun sampai delapan belas tahun. Hasil survei menunjukan bahwa para peserta didik mayoritas menggunakan smartphone.

\section{Metode Penelitian}

\section{A. Konsep Penelitian}

Memulai dengan mendatangi ke lokasi penelitian yaitu Madrasah Diniyah Baitul Athfal beralamat di Desa Arenan RT 003/001 Kecamatan Kaligondang Kabupaten Purbalingga, Jawa Tengah. Selanjutnya melakukan wawancara dari Bapak Iskandar Zulkarnainselaku Kepala Madrasah Diniyah Baitul Athfal. Setelah itu melakukan observasi kegiatan Madrasah Diniyah Baitul Athfal serta mencari referensi berupa jurnal publikasi maupun buku cetak nasional. Setelah mendapatkan permasalahan dari pengumpulan data, peneliti melakukan pengembangan sistem dengan metode yang sudah ditentukan dan lebih relevan yaitu menggunakan motode Multimedia Developent Life Cycle (MDLC). Setelah proses pengembangan sistem selesai maka peneliti membuat laporan hasil dari penelitian ke pihak yang terkait dengan cara mempublikasi hasil penelitian.

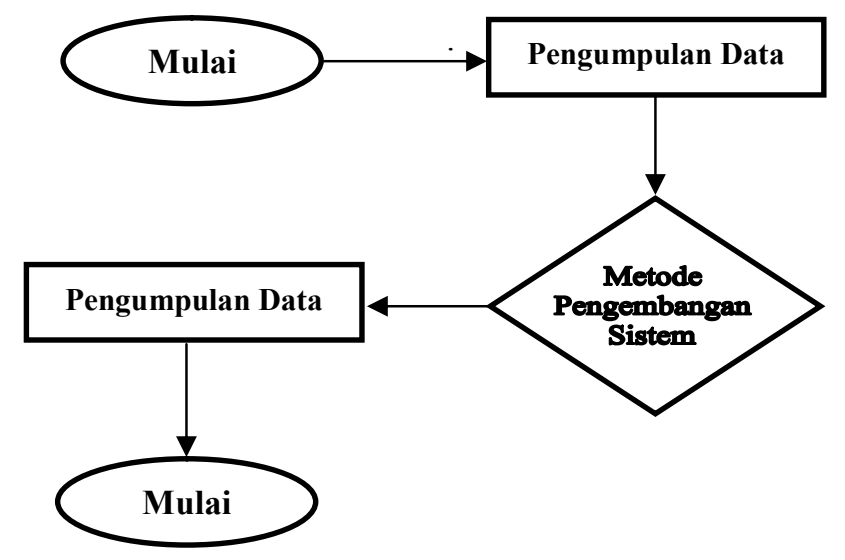

Gambar 1. Kerangka Penelitian 


\section{B. Metode Pengumpulan Data}

Instrumen penelitian yang digunakan adalah merupakan teknik untuk mengumpulkan data apabila peneliti ingin melakukan pendahuluan untuk menemukan permasalahan yang harus diteliti [7]. Pada penelitian ini wawancara dilakukan dengan cara bertanya secara langsung kepada pengajar Madrasah Diniyah Baitul Athfal untuk mendapatkan informasi yang diperlukan dalam penelitian. Teknik pengumpulan data dengan observasi digunakan bila penelitian berkenaan dengan merilaku manusia, proses kerja, gejala gejala alam dan bila responden yang diamati tidak terlalu besar [8].

Observasi pada penelitian ini dilakukan dengan cara datang dan mengamati proses pembelajaran pengurusan jenazah di Madrasah Diniyah Baitul Athfal. Kuesioner merupakan teknik pengumpulan data yang dilakukan dengan memberi seperangkat pertanyaan atau pernyataan tertulis kepada responden untuk dijawabnya [9].

Pada penelitian ini kuesioner digunakan untuk mengetahui seberapa dominan smartphone digunakan oleh murid Madrasah Diniyah Baitul Athfal. Studi kepustakaan dilakukan untuk mencari landasan teori dari berbagai literatur yang berkaitan dengan masalah penelitian.

Studi kepustakaan dilakukan dengan membaca bukubuku perpustakaan, serta literatur lain yang berkaitan dengan penelitian Pada penelitian ini, penulis mengumpulkan data-data yang dibutuhkan melalui studi pustaka misalnya berupa buku, jurnal, skripsi dan lain sebagainya.

\section{Metode Pengembangan Sistem}

Dalam penelitian ini metode pengembangan sistem yang digunakan adalah Multimedia Developent Life Cicle. Metodelogi ini tepat diterapkan dalam pengembangan perangkat lunak berbasis multimedia [10]. Dalam pengembangan perangkat lunak multimedia membutuhkan metode tersendiri yang tidak sama dengan metode pengembangan perangkat lunak klasik.

Hal ini disebabkan multimedia merupakan kombinasi dari elemen teks, gambar diam/foto/seni grafis, suara, animasi, dan video yang dimanipulasi secara digital. Pengembangan multimedia terdiri dari enam tahapan, yaitu concept (pengonsepan), design (perancangan), material collecting (pengumpulan materi), assembly (pembuatan), testing (pengetesan) dan distribution (pendistribusian) [11], seperti pada Gambar 2. Alur Proses MDLC:

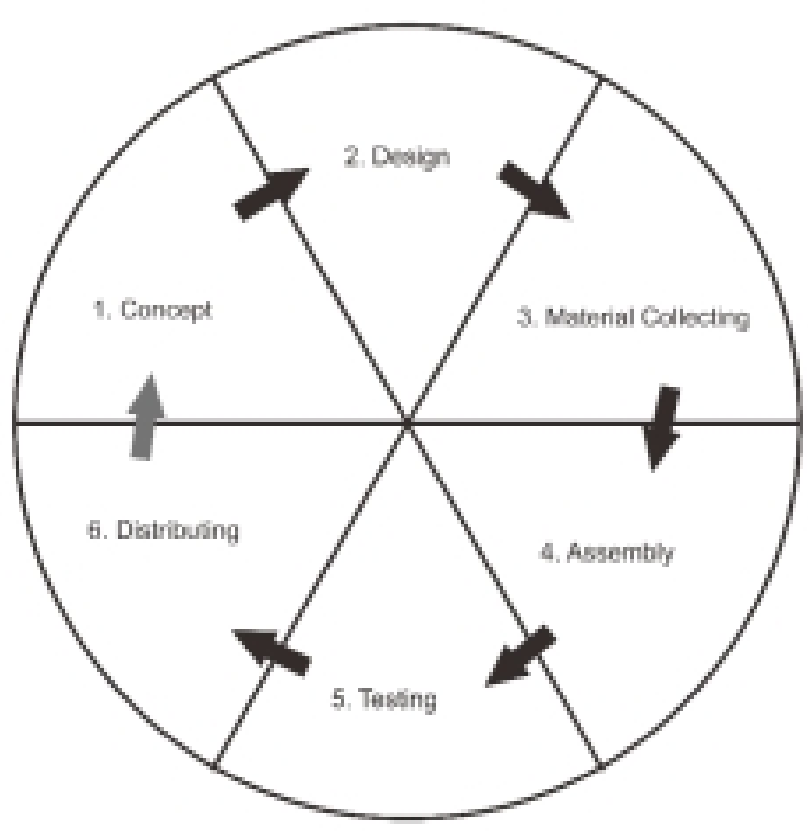

Gambar 2. Alur Proses MDLC

\section{Hasil dan Pembahasan}

Tahapan pengembangan sistem menggunakan MDLC sebagai berikut:

1. Concept

Aplikasi yang dibangun adalah aplikasi pembelajaran yang memuat materi pengurusan jenazah mulai dari menghadapi orang sakaratul maut, 30 yang dilakukan setelah orang yang sakaratul maut meninggal dunia, memandikan jenazah, mengkafani jenazah, menshalati jenazah, sampai dengan menguburkan jenazah. Pada materi terdapat beberapa gambar dan animasi singkat. Aplikasi juga dilengkapi dengan kuis untuk menguji kemampuan siswa dalam memahami materi pengurusan jenazah. Beberapa elemen multimedia meliputi teks, gambar, suara dan animasi diterapkan pada aplikasi ini.

2. Design

Setelah menentukan konsep, tahapan selanjutnya adalah melakukan design. Pada tahap design yang dilakukan adalah membuat perancangan untuk menggambarkan deskripsi tiap scene. Storyboard digunakan untuk mengambarkan deskripsi tiap scene dan struktur navigasi digunakan untuk menggambarkan alur dari satu scene ke scene lainnya.

\section{a. Storyboard}

Dibuat sesuai dengan konsep yang telah dibuat. Hasil storyboard akan digunakan sebagai acuan pada tahap pembuatan aplikasi sesuai dengan pada Tabel 1 . Storyboard Aplikasi: 
Tabel 1. Storyboard Aplikasi

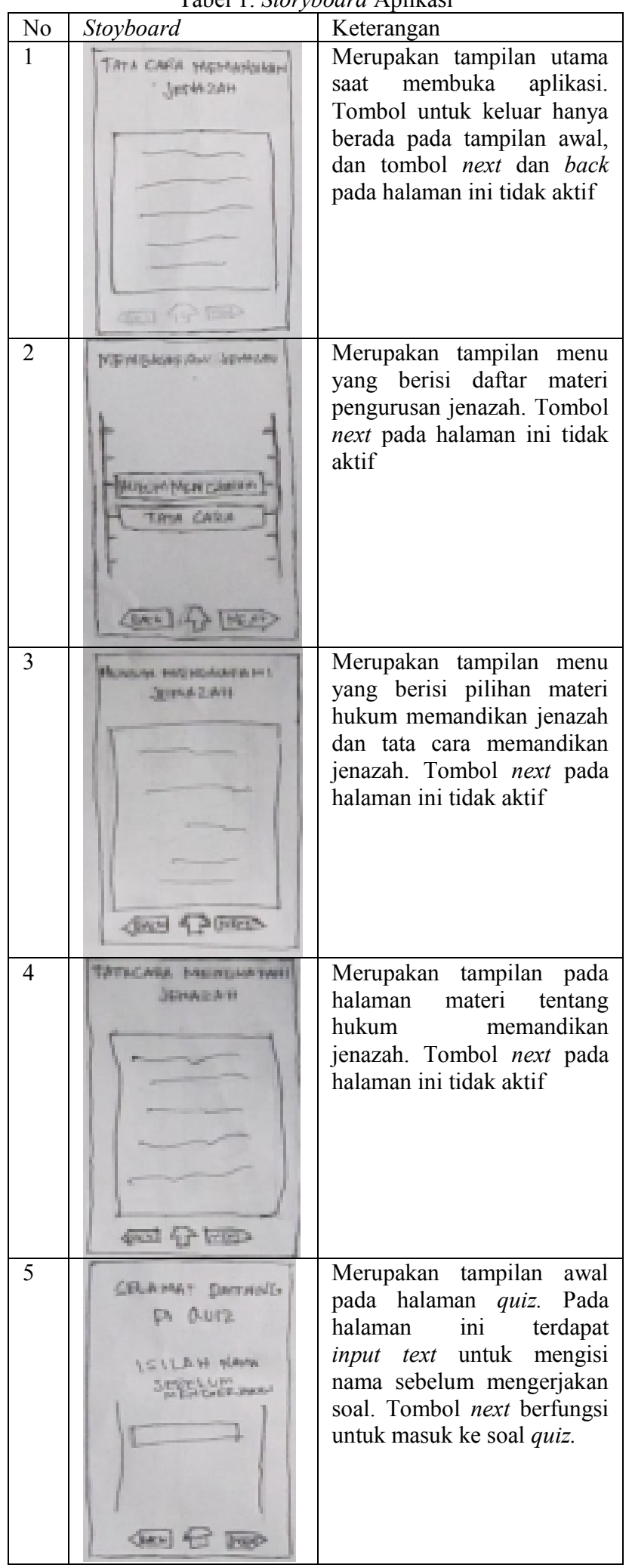

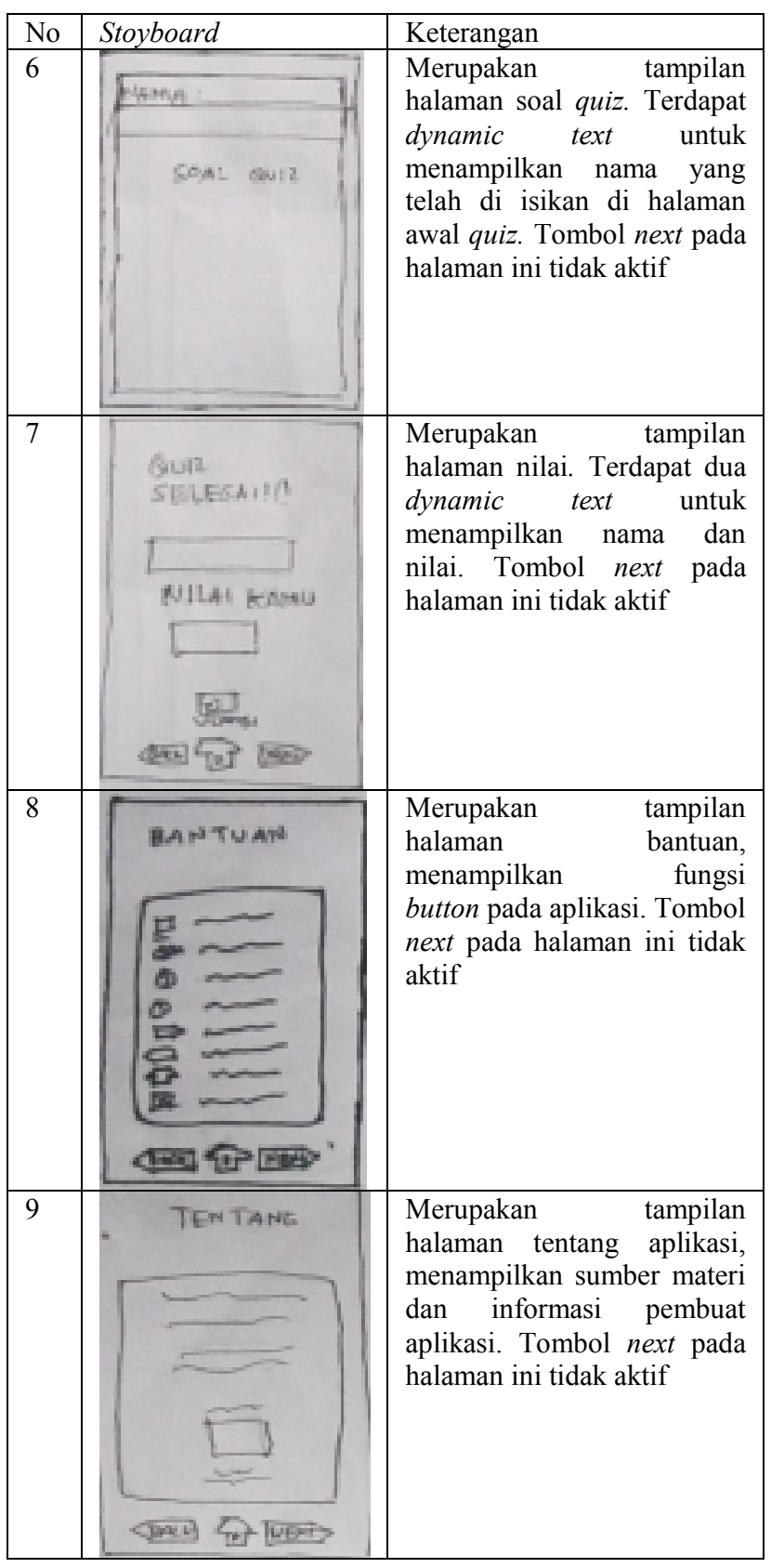

b. Struktur Navigasi

Dibuat sesuai dengan alur yang telah direncanakan sehingga memudahkan dalam pembuatan. Berikut struktur navigasi aplikasi Pembelajaran Pengurusan Jenazah Muslim. 


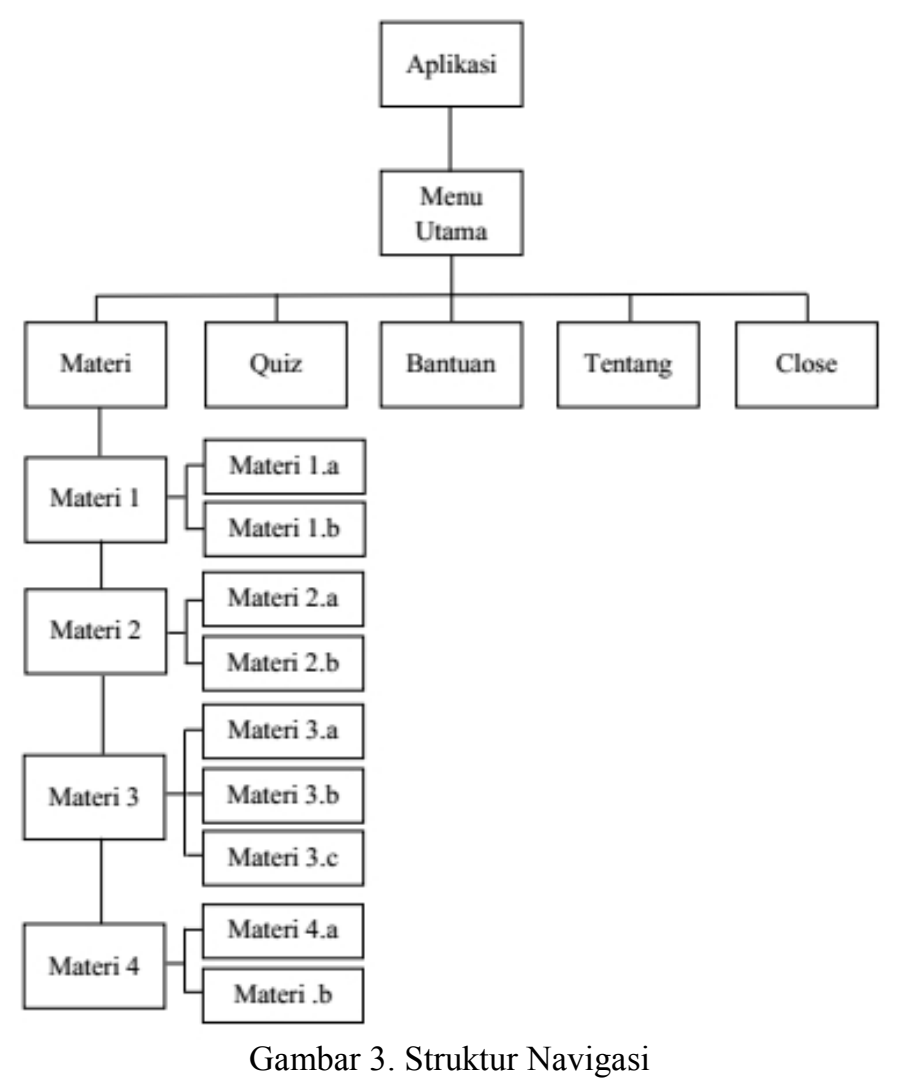

3. Material Collection

Pada tahap ini, materi dan bahan yang dibutuhkan dalam pembuatan aplikasi dikumpulkan. Bahan yang dikumpulkan antara lain gambar, teks, serta animasi. Berikut adalah pengumpulan bahan pembuatan aplikasi Pembelajaran Pengurusan Jenazah Muslim. Untuk tampilan Background dibuat menggunakan aplikasi dengan Blender 3D, sedangkan $\mathrm{F}_{-}$Awal, F_Materi, $\mathrm{F}_{-}$ Bantuan, F_Quiz, F_Soal, F_Nilai, F_Tentang, Box, F_HukMan, F_HukFan, F_HukBur, F_HukShal, F_Memandikan, F_NiatShal, F_Mengkafani, F_Kuburkan, F_Shalat, F_Meninggal, F Tatafan, F_TataKubur, F_TataMandi dam F_TataShal dibuat menggunakan aplikasi Adobe Photoshop.

Untuk Button seperti App icon dibuat menggunakan Blender 3D dan pengeditan dengan Adobe Photoshop, sedangkan Icon Home_exit, Hukum_btn, Materi_btn, Tacara_btn, Back_btn, Next_btn, Bantuan_btn, Tentang_btn, Materi1_btn, Quiz_btn dan Niatshal_btn, serta gambar Allah SWT, Ashädu, Ashadu_Lengkap, D_CakupanKe1, D_CakupanKe2, D_CakupanKe3, D_ApabilaAnak, D_Memejamkan, D_Mewudukan, D_MemasukanLiang, $\quad$ H_BerlebihanKainKafan, H_CacatTubuh, H_KafanPutih, H_Kafir \& Munafik, H_Kubur, $\quad$ H_MembacaAlfatihah, H_MeninggalSebelumSaya, H_SebaiknyaKeluarga,
H_Takbir4X, Lailahaillalah, N_AnakLaki, N_AnPerempuan, N_BelumJelasAgamanya, N_ N_Laki- N_PerempuanDewasa, N_IdentitasJenazah, Salam, TakbirKe2, TakbirKe3, TakkbirKe4, dibuat menggunakan dengan Aplikasi CorelDRAW X7

Untuk Gambar seperti Di_tengkurap, Sisir dan Tangan_sarung dibuat menggunakan aplikasi Blender $3 D$ dan pengeditan menggunakan Adobe Photoshop, sedangkan Animasi Siram dan Urut perut, dibuat menggunakan aplikasi Blender $3 D$ dan proses convert menggunakan Any Video Converter. Sedangkan suara seperti Hooray dan Button_sound dihasilkan dengan ekstensi .MP3.

\section{Assembly}

Pada Tahapan Assembly semua bahan okum edia dibuat. Pembuatan berdasarkan pada tahap design seperti storyboard dan struktur navigasi. Pembuatan aplikasi pembelajaran pengurusan jenazah menggunakan Adobe Flash CS6.

Berdasarkan Gambar 4, Menu Utama merupakan tampilan menu utama. Saat user menjalankan aplikasi maka akan langsung masuk ke menu utama. Pada tampilan utama terdapat lima button yaitu materi, quiz, bantuan, tentang, dan keluar.

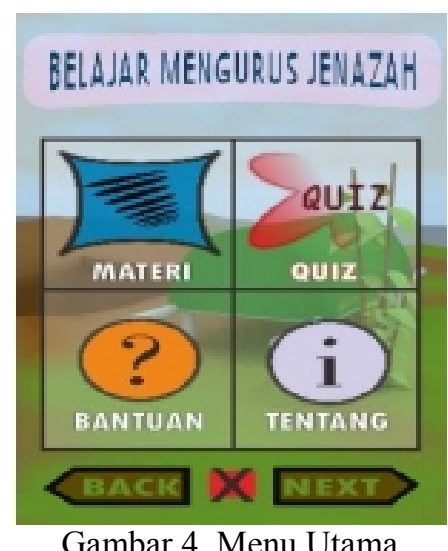

Berdasarkan Gambar 5. Menu Materi menampilkan beberapa pilihan materi. Terdapat juga button back dan home. Seperti Materi Memandikan yang nantinya berisi materi okum memandikan dan tata cara memandikan. Kemudian Materi Hukum Memandikan Jenazah. Materi Tata Cara Memandikan, Materi Mengkafani Jenazah, terdapat dua pilihan materi yaitu okum mengkafani dan tata cara mengkafani. Materi Menshalati Jenazah, Materi Niat Menshalati Jenazah, Materi Tata Cara Menshalat Jenazah, Materi Menguburkan Jenazah, terdapat dua pilihan materi yaitu okum menguburkan dan tata cara menguburkan jenazah. 


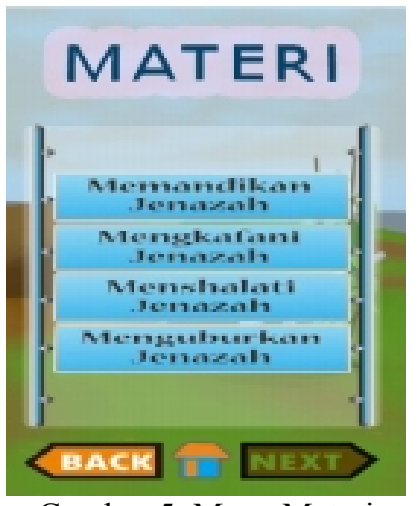

Gambar 5. Menu Materi

Berdasarkan Gambar 6. Halaman Awal Quiz merupakan tampilan halaman awal sebelum mengerjakan soal-soal quiz. Pada halaman ini seberlum mengerjakan dianjurkan mengisi nama terlebih dahulu. Setelah mengisi nama maka selanjutnya menekan tombol Next untuk langsung mengerjakan soal-soal.

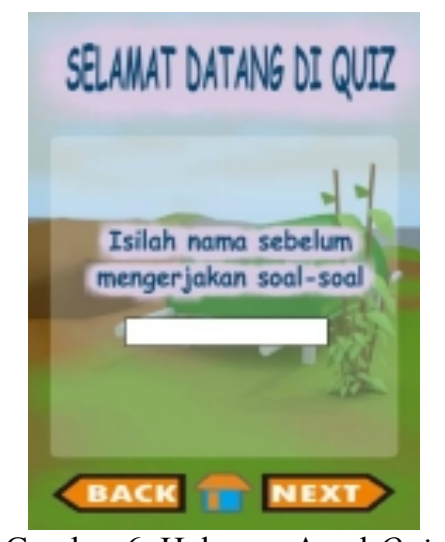

Berdasarkan gambar 7. merupakan tampilan halaman Quiz. Pada halaman quis terdapat tombol home untuk kembali ke halaman menu utama aplikasi. Jika soal quis sudah di jawab maka akan langsung menuju ke soal berikutnya. Jumlah soal quiz pada aplikasi berjumlah 25 soal pilihan ganda.

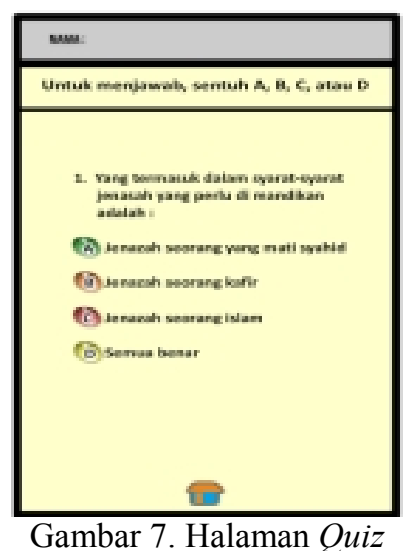

Berdasarkan Gambar 8. Halaman Nilai, merupakan tampilan halaman nilai. Pada halaman ini, nilai dari quiz di tampilkan. Terdapat tombol home untuk kembali ke halaman menu utama aplikasi dan juga tombol ulangi untuk mengulaingi mengerjakan soal-soal.

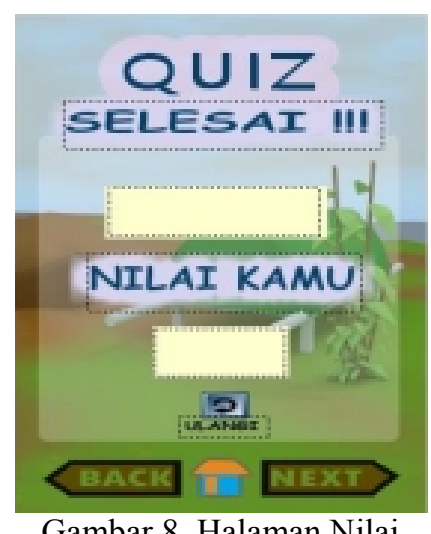

Berdasarkan Gambar 9. Halaman Bantuan merupakan tampilan halaman bantuan. Menampilkan penjelasan tentang button yang terdapat pada aplikasi.

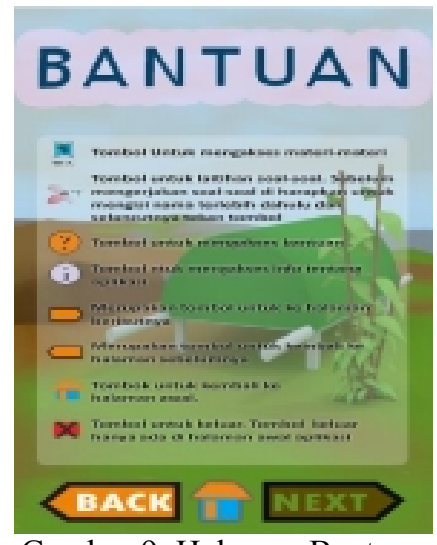

Gambar 9. Halaman Bantuan

\section{Testing}

Pengujian dilakukan untuk memastikan komponen pada aplikasi sudah berjalan sesuai dengan yang diharapkan. Dalam aplikasi ini proses pengujian dilakukan dengan dua metode, yaitu: pengujian alpha dan beta.

Pengujian alpha dilakukan oleh pembuat itu sendiri, sedangkan pengujian beta melibatkan pengguna. Aplikasi Pengurusan Jenazah dilakukan pada setiap scene untuk melihat apakah ada kesalahan fungsi atau tidak. Untuk Hasil secara keseluruhan dari setiap scene sudah berjalan sangat baik dan apabila terjadi kesalahan pada saat pengujian maka langsung dilakukan proses perbaikan. 
Tabel 2. Skala Performa

\begin{tabular}{|c|c|l|}
\hline Skala & Nilai & \multicolumn{1}{c|}{ Keterangan } \\
\hline SS & 5 & $\begin{array}{l}\text { Aplikasi pembelajaran memiliki performa } \\
\text { yang sangat baik }\end{array}$ \\
\hline S & 4 & $\begin{array}{l}\text { Aplikasi pembelajaran memiliki performa } \\
\text { yang baik }\end{array}$ \\
\hline N & 3 & $\begin{array}{l}\text { Aplikasi pembelajaran memiliki performa } \\
\text { yang sedang }\end{array}$ \\
\hline TS & 2 & $\begin{array}{l}\text { Aplikasi pembelajaran memiliki performa } \\
\text { yang buruk }\end{array}$ \\
\hline STS & 1 & $\begin{array}{l}\text { Aplikasi pembelajaran memiliki performa } \\
\text { yang sangat buruk }\end{array}$ \\
\hline
\end{tabular}

Berdasarkan Tabel 2. Skala Performa, terbagi menjadi lima bagian yaitu Sangat Baik bernilai 5, Baik bernilai 4, Sedang bernilai 3, Buruk bernilai 2 dan Sangat Buruk bernilai 1 .

Tabel 3. Keterangan Penilian

\begin{tabular}{|c|c|c|c|c|c|}
\hline No. & \multicolumn{5}{|c|}{ Penilaian } \\
\hline 1 & SS & S & N & TS & STS \\
\hline 2 & 35 & 45 & 4 & 0 & 0 \\
\hline 3 & 43 & 25 & 15 & 1 & 0 \\
\hline 4 & 12 & 60 & 10 & 2 & 0 \\
\hline 5 & 18 & 63 & 2 & 1 & 0 \\
\hline 6 & 45 & 30 & 9 & 0 & 0 \\
\hline 7 & 67 & 15 & 2 & 0 & 0 \\
\hline 8 & 73 & 10 & 1 & 0 & 0 \\
\hline 9 & 50 & 30 & 4 & 0 & 0 \\
\hline 10 & 67 & 14 & 2 & 1 & 0 \\
\hline 11 & 82 & 2 & 0 & 0 & 0 \\
\hline 12 & 14 & 52 & 15 & 3 & 0 \\
\hline 13 & 28 & 56 & 0 & 0 & 0 \\
\hline 14 & 68 & 10 & 6 & 0 & 0 \\
\hline 15 & 35 & 47 & 2 & 0 & 0 \\
\hline 16 & 34 & 27 & 20 & 3 & 0 \\
\hline 17 & 21 & 48 & 15 & 0 & 0 \\
\hline 18 & 46 & 35 & 3 & 0 & 0 \\
\hline 19 & 22 & 48 & 14 & 0 & 0 \\
\hline 20 & 19 & 59 & 6 & 0 & 0 \\
\hline 21 & 68 & 16 & 0 & 0 & 0 \\
\hline 22 & 64 & 11 & 9 & 0 & 0 \\
\hline 23 & 37 & 35 & 12 & 0 & 0 \\
\hline 24 & 79 & 5 & 0 & 0 & 0 \\
\hline 25 & 65 & 15 & 4 & 0 & 0 \\
\hline Total & 1139 & 785 & 165 & 11 & 0 \\
\hline & & & & & \\
\hline
\end{tabular}

Sedangkan pengujian Beta Pada tahap ini aplikasi Pengurusan Jenazah dilakukan uji kelayakan kepada guru dan siswa di Madrasah Diniyah Baitul Athfal menggunakan kuesioner dengan total pernyataan sebanyak dua puluh lima dan nilai dari setiap pernyataan dapat dilihat pada Tabel 3. Keterangan Penilian.

Dari hasil pernyataan yang diperoleh, responden yang memberikan tanggapan Sangat Baik sebesar 1.139, Baik sebesar 785, Sedang sebesar 165, Buruk 11 dan Sangat Buruk tidak ada yang memberikan tanggapan.
Dari hasil yang ada untuk penilaian menggunakan rumus:

Keterangan:

$$
Y=X \times \alpha
$$

$\Upsilon=$ Skala

$\mathrm{X}=$ Hasil Pernyataan

$\alpha=$ Skala Pernyataan

Maka:

$\Upsilon=1139 \times 5$

$=5695$

$\Upsilon=785 \times 4$

$=3140$

$\Upsilon=165 \times 3$

$=495$

$\mathrm{Y}=11 \times 2$

$=22$

$\mathrm{Y}=0 \times 1$

$=0$

Selanjutnya berdasarkan Gambar 10. Skala Kategori, menghasilkan perhitungan dari rumus sebagai berikut:

$$
Y=X \times \alpha \times b
$$

Keterangan:

$\Upsilon=$ Skala

$\mathrm{X}=$ Nilai Skala likert

$\alpha=$ jumlah responden

$b=$ Total Pernyataan

Maka:

$\gamma=5 \times 84 \times 25$

$=13.000$ (Sangat Baik)

$\mathrm{Y}=4 \times 8 \times 25$

$=8.400$ (Baik)

$\mathrm{Y}=3 \times 84 \times 25$

$=6.300$ (Sedang)

$\mathrm{Y}=2 \times 84 \times 25$

$=4.200$ (Buruk)

$\mathrm{Y}=1 \times 84 \times 25$

$=2.100$ (Sangat Buruk)

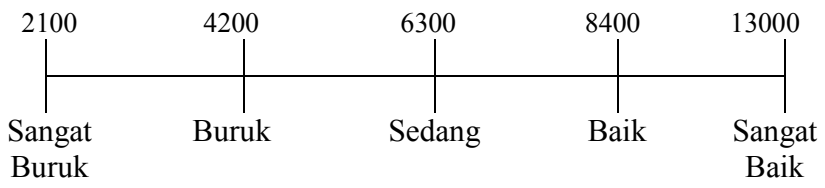

Gambar 10. Skala Kategori

Berdasakan hasil yang didapatkan maka tahap selanjutnya adalah tambahkan secara keseluruhan:

$\mathrm{Y}=\mathrm{SS}+\mathrm{S}+\mathrm{N}+\mathrm{TS}+\mathrm{STS}$

$=5695+3140+495+22+0$

$=9352$ 
Dengan hasil yang ada sebesar 9352 masuk kategori Baik dan dapat diterapkan pada objek penelitian.

\section{Distribution}

Setelah aplikasi Pengurusan Jenazah selesai diuji, maka tahap selanjutnya adalah proses pendistribusian. Pada tahap ini, distribusi dilakukan dengan menyimpan aplikasi dalam perangkat smartphone dalam bentuk format apk. Pendistribusian aplikasi ini dibagikan kepada siswa Madrasah Diniyah Baitul Athfal.

\section{Kesimpulan}

Berdasarkan penelitian yang dilakukan di Madrasah Diniyah Baitul Athfal Desa Arenan Purbalingga, yang meliputi concept, design, material collecting, assembly, testing dan distibution dapat diambil kesimpulan sebagai berikut:

1. Telah berhasil dibuat aplikasi pembelajaran pengurusan jenazah pada Madrasah Diniyah Baitul Athfal Desa Arenan Purbalingga.

2. Aplikasi pengurusan jenazah menyediakan fasilitas berupa materi dan quiz guna menunjang proses belajar murid.

3. Berdasarkan hasil penilaian siswa dan guru Madrasah Diniyah Baitu Athfal, aplikasi layak digunakan sebagai media belajar pengurusan jenazah.

\section{Daftar Pustaka}

[1] M. Rifai, Ilmu Fiqih Islam Lengkap. Semarang: CV. Toha Putra, 1978

[2] A. Riyadi, "Upaya Pemberdayaan Dan Peningkatan Keterampilan Pemulasaraan Jenazah Di Wilayah Kecamatan Mijen Kota Semarang," J. Pemikir. Agama Untuk Pemberdaya., vol. 13, 2013.

[3] A. Rachman, Fathor., \&., Maimun, "Madrasah Diniyah Takmiliyah (MDT) Sebagai Pusat Pengetahuan Agama Masyarakat Pedesaan (Studi tentang Peran MDT Di Desa Gapura Timur Gapura Sumenep)," J. Kebud. dan Ilmu Keislam., vol. 9, 2016.

[4] A. Hanim, Fitria., Sumarni., \&., Amirudin, "Pengaruh Penggunaan Multimedia Pembelajaran Interaktif Penginderaan Jauh Terhadap Hasil Belajar Geografi," $J$. Pendidik., vol. 1, 2016.

[5] G. Kartikasari, "Pengaruh Media Pembelajaran Berbasis Multimedia Terhadap Motivasi Dan Hasil Belajar Materi Sistem Pencernaan Manusia Studi Eksperimen pada Siswa Kelas V MI Miftahul Huda Pandantoyo," J. Din. Penelit. Media Komunikas Penelit. Sos. Keagamaan, vol. 16, 2016.

[6] P. Wirawan, "Pengembangan Kemampuan E-learning Berbasis Web Ke Dalam M-learning, Jurnal Masyarakat Informatika," J. Masy. Inform., vol. 2, 2011.

[7] Sugiyono, Metode Penelitian Kuantitatif, Kualitatif R\&D. 2017.

[8] Jogiyanto, Pengembangan Bahan Ajar Metode Penelitian Pendidikan Dengan Addie Model. Yogyakarta: Andi, 2008.

[9] A. Kristanto, Perancangan Sistem Informasi. Yogyakarta: Gava Media, 2018.

[10] Munir, Kurikulum Berbasis Teknologi Informasi dan Komunikasi. Bandung: Alfabeta, 2008.

[11] I. Binanto, Multimedia Digital, Dasar Teori + Pengembangannya. Yogyakarta: CV. Andi Offset, 2010. 